\title{
THE RULE IN PHILLIPS V. EYRE
}

\author{
EDWIN A. TOLLEFSON*
}

Perhaps no rule in conflict of laws has been subjected to as much criticism as the rule laid down by Willes, J., in Phillips v. Eyre. ${ }^{1}$

Briefly, the facts were that the defendant, Governor Eyre of the island of Jamaica, was being sued for assault and false imprisonment. He pleaded in defence that the injuries had occurred during a rebellion, and that since that time an Act of Indemnity had been passed by the Legislature of the Island and assented to by the Crown, whereby he and all officers and other persons who had acted under his authority were indemnified in respect of all acts done in order to suppress the rebellion, and all such acts were thereby made and declared lawful. It was argued by the plaintiff that no extra-territorial effect should be given to the Act, but the Court of Exchequer Chamber decided to the contrary, holding that as Governor Eyre would have had a valid defence to the action if it had been brought in Jamaica, he could not be found liable in an English court. Willes, J., in delivering the judgment of the Court, set out the following rule regarding choice of law in cases based on wrongs alleged to have been committed abroad:

First, the wrong must be of such a character that it would have been actionable if committed in England .... Secondly, the act must not have been justifiable by the law of the place where it was done.2

There is no doubt that the rule as stated by Willes, J., is the law in Canada. For those jurisdictions which have received English law up to July $15,1870,{ }^{3}$ the Phillips v. Eyre decision is direct authority, having been decided on June 23, 1870. What is more, the rule has been approved and applied several times by the Privy Council and the Supreme Court of Canada." Therefore, until the rule is changed by legislation, our courts are bound to follow it.

In view of the number of decisions which have followed the rule in Phillips v. Eyre, it is surprising that the texts on private international law should persist in restating the second arm of the rule wrongly. Cheshire, ${ }^{5}$ Dicey, ${ }^{6}$ Schmitthoff, ${ }^{7}$ and Wolff ${ }^{8}$ all discuss this part of the rule as if it involved determination of the justifiability of the act by reference to the lex loci delicti. This interpretation requires that the second arm of the rule ("Secondly, the act must not have been justifiable by the law of the place where it is done") be read as if the pronoun "it" referred to the "wrong"; whereas the only possible antecedent in the sentence is the word "act." The question of justification is to be determined, therefore, not by reference to the lex loci delicti, but by reference to

- Associate Professor of Law, University of Saskatchewan, Saskatoon.

1 (1870), 6 Q.B. 1.

$\because$ Ibid., at 28-29.

$\because$ Manitoba, Saskatchewan and Alberta.

4 Walpole v. C.N.R. [1923] A.C. 113; McMillan v. C.N.R., [1923] A.C. 120; McLean v.

Pettigrew, [1945] S.C.R. 62; Canadian National Steamship Co. v. Watson, [1939] S.C.R.

11. The rule has also been approved in the House of Lords in Cart v. Fracis Times \& Co., [1902] A.C.176.

$\therefore$ Cheshire, Private International Law Ch. 10 (6th ed. 1961).

"Dicey's Conflict of Laws Ch. 28 (7th ed. 1958).

i Schmitthoff. The English Conflict of Laws Ch. 6 (3rd ed. 1954).

hWolff, Private International Law Ch. 30 (and ed. 1950). 
the lex loci actus. In most cases all the elements of the tort will have occurred within the bounds of one jurisdiction; hence, whether the reference is to the lex loci delicti or the lex loci actus, the end result will be the same. However, where the act occurs in one jurisdiction and the injury occurs in another this happy coincidence will not necessarily exist. Our courts have yet to declare any firm rule on how to determine the locus delicti where the act and the injury occur in different juridictions. They might logically adopt Dr. Cheshire's view that, inasmuch as there is no tort until there has been an injury, the place where the injury occurred should be considered the place of the tort. ${ }^{9}$ In other words, reference to the lex loci delicti can lead to a result inconsistent with the rule in Phillips v. Eyre. Use of the term lex loci delicti in this context should therefore be avoided, as it only serves to confuse the issue.

Even though the second arm of the rule is simple enough to apply when read properly, it is often criticised as being a choice of law rule which does not lead to a sensible result in all cases. ${ }^{10}$ This would appear to be particularly evident in cases involving two or more persons who just happened to be passing through the jurisdiction at the time the injury occurred. That their tortious liability towards each other should be determined by the lex loci actus seems to be a trifle mechanical. Perhaps legislation should be enacted to have such cases decided on the basis of the law of the place most closely associated with the wrong, i.e., according to the proper law of the tort-to use Dr. J. H. C. Morris' expression. ${ }^{11}$ This would be a simple and honest solution, but the legislatures are notoriously slow in enacting remedial legislation of this nature, and in the meantime the courts are required to work within the confines of the Phillips v. Eyre rule. One possible means of providing flexibility was indicated by the New York Court of Appeals in the recent case of Babcock v. Jackson. ${ }^{12}$ The facts were that two residents of New York were on a motor trip together in the defendant's car. While driving in Ontario, the plaintiff, who was a gratuitous passenger, was injured in an accident which allegedly resulted from the defendant's negligence. Ontario legislation would have precluded the gratuitous passenger from recovering any compensation from the driver on the basis of simple negligence, but New York law had no such limitation. The majority of the Court of Appeals quite frankly applied New York law to the case

o Cheshire, ante, n. 5, 294-95.

10 The second arm of the rule is also criticised because of the use of the word "justifiable." Both Cheshire and Dicey condemn the usage as ambiguous. They point out that if the word is given a wide interpretation the defendant may be in a worse position if he is sued in England than he would have been if he had been sued in the courts of the locus actus: see Machado v. Fontes, [1897] 2 Q.B. 231 , where the plaintiff sued the defendant for a libel published in Brazil, and the defendant's plea that no civil action lay in Brazil was rejected by the English court because his act was not justifiable. inasmuch as libel was considered to be a criminal offence in Brazil. Cheshire and Dicey suggest that this permits the plaintiff to go forum-shopping to find a jurisdiction where substantial damages may be recovered in respect of the act. To prevent such chicanery they suggest that the word "justifiable" should be read as meaning "actionable." If no action lies in the locus actus, none should lie in England. It is doubtful whether this interpretation is permissible in Canada, in view of the decision in McLean v. Pettigrew, [1945] S.C.R. 62. Furthermore, the term "justifiable" does not appear to be quite as ambiguous in Canada as in England. In the case of Walpole v. C.N.R. [1923] A.C. 113, the Privy Council said that the term obviously must refer to "legal justification." and that "An act or neglect which is neither actionable nor punishable cannot be said to be otherwise than justified" (p. 119). This would mean that acts which by the lex loci actus were only morally wrong could not be the basis of a cause of action in Canada.

11 Morris, The Proper Law of a Tort (1951), 64 Harv. L.R. 881. 12 N.Y. (2d) 473 . This case is reported and extensively commented upon in (1963),
63 Colum. L.R. 1212 . 
and disregarded Ontario law as having nothing to do with this sort of a factual situation. But it is interesting to note that, even though the New York court was not bound by the rule in Phillips v. Eyre, it still considered whether Ontario law was intended to apply to foreigners who were just passing through the province. The court came to the conclusion on this inquiry that the Ontario legislation on gratuitous passengers was intended to protect Ontario insurance companies from fraudulent claims and had no application to actions against New York drivers and their insurance carriers. ${ }^{13}$ Read as a reference to the whole of the lex loci actus, therefore, the rule in Phillips v. Eyre would appear to have sufficient flexibility to permit the court to do justice in most cases.

The apparent conclusion to be drawn from the foregoing discussion is that most of the criticism of the second arm of the rule in Phillips v. Eyre is not "justifiable." 